\title{
The Influence of Transformational Leadership on Employee Job Satisfaction with Organizational Commitment as Intervening Variable
}

\author{
SITI MUNFAQIROH \\ Malangkucecwara School of Economic, Indonesia \\ E-mail: riroh@stie-mce.ac.id \\ HANIF MAULUDIN (Corresponding Author) \\ Malangkucecwara School of Economic, Indonesia \\ E-mail: hanif@stie-mce.ac.id \\ ANGGI SUHENDAR \\ Malangkucecwara School of Economic, Indonesia \\ E-mail: anggisuhendar1403@gmail.com
}

Received: Dec. 28, 2020 Accepted: Jan. 23, $2021 \quad$ Online published: Feb., 2021

doi:10.5296/ijhrs.v11i1.18270ＵRL: https://doi.org/10.5296/ijhrs.v11i1.18270

\begin{abstract}
The purpose of this study was to determine the effect of transformational leadership on employee job satisfaction with employee organizational commitment as an intervening. The sample used in this study amounted to 50 employees of PT Andhika Lines. East Java. Indonesia. The data collection method used in this study was a questionnaire. In this study, data analysis used the Partial Least Square (PLS) approach using the Smart PLS software.The results showed that transformational leadership was not proven to have a significant effect on job satisfaction, but transformational leadership had a positive and significant effect on job satisfaction with organizational commitment as an intervening variable. Transformational leaders are believed to be able to bring better change and can improve employee performance. Transformational leadership, is a stage that changes people in a team, leaders who use this style motivate their followers to give and work more than they can or want, even beyond their
\end{abstract}


ability.

Keywords: transformational leadership, organizational commitment, job satisfaction

\section{Introduction}

HR management is now a necessity and is no longer an option if a company wants to grow. Even to survive in the business world in the era of the industrial revolution 4.0 only where there are so many changes, especially in the use of human resources that have been limited because they are replaced by automation machines and others that can make employee productivity levels decrease due to anxiety arising from that era. This makes leaders have to think extra to react to it. Plus the existence of a business phase VUCA WORD or Volatile (volatile), Uncertain (uncertain), Complex (complex), and Ambiguity (unclear) are being faced by all companies big or small though (Aribowo and Alexander. 2018). This phase actually makes business people work even harder to think of a solution. Therefore, the basic concept of transformational leadership in HR management of this model is clearly formed to combat this precarious situation. Bushra, Ahmad and Asvir (2011) which states that the organization can develop, one of which is through continuous and sustainable improvements on all sides.

Transformational leaders are believed to be able to bring better change and can improve the performance of their employees, this is also confirmed by Kala'lembang, Budi and Sutrisno (2015) that employee management is very dependent on the leadership qualities of the organization. Under good leadership, employees can have high initiative and care, clearer guidance and direction and better coordination can greatly help strengthen emotional bonds with their subordinates (Pratama .2016). The company must have a leader who have better understanding on the situation around its employees, both in terms of mood and work environment, because simple things can affect enthusiasm and optimism among employees which results in the productivity of great innovations for the company (Jyoti and Sonia. 2015). Transformational leadership has a very positive impact on empowering the scope of workers, the results of which can warm the productive work atmosphere and increase job satisfaction as a useful strategy for the success of the companies (Khanzada, Shahzad and Hashim. 2018). To improve the innovative work behavior of employees in a company, leaders in the organization must strive to involve themselves effectively in the work of their employees.

Transformational leadership, is a stage that changes people in a team, leaders who use this style motivate their followers to give and work more than they can or want, even beyond their ability. Transformational leaders tend to have dedicated and satisfied followers, furthermore they empower their employees, pay attention to their needs and development, helping them foster a larger sense of compassion for the company (li et al. 2019).

Every leader has different talents, companies need to have talent mapping for the selected structural positions. Talent mapping is used to identify candidate leaders who have competence and match the conditions of employees with diverse characters and work environments with the aim of being more successful in increasing organizational commitment and employee job satisfaction (Eliyana, Syamsul and Muzakki .2019). 
Organizational commitment and employee job satisfaction is one of the important things in a company that really wants to develop properly. All of these things, of course, must be supported by organizational leadership that has interpersonal skills and is accepted by all employees in an organization who are able to create this.

PT Andhika Lines. East Java. Indonesia is a national shipping company that is engaged in the operation and management of ships, logistics, loading and unloading of ships, custom clearance for export imports and heavy equipment rental. In this company there are no problems regarding employee performance, alternating leadership does not significantly affect the decline in employee performance because the reward and punishment strategy in this company is running, where every employee who has good performance according the work targets in their divisions will receive a reward from either company in form of material or just appreciation, but on the other hand when an employee makes a mistake or doesn't meet the expected target, the employee gets a punishment either verbally or other punishment. which means that the employee's performance is still in a good state. However, the authors found that the level of employee satisfaction was less than optimal which was obtained from the results of closed interviews between the authors and representatives of employees of PT Andhika Lines. East Java. Indonesia. This means that there is an end result of good employee performance but found the level of employee satisfaction and organizational commitment that should be improved. The previous leadership was applying rewards and punishments to employees, in this case the leadership style still included as a transactional leadership where leaders motivate employees with awards to increase the morale of their followers. Meanwhile, transformational leadership is an important factor that affects employee job satisfaction and organizational commitment and organizational commitment to employee job satisfaction. The success of the employees is a factor in the success of the leader for the achievement in managing employees (Prabandari and Asri. 2018).

Employee job satisfaction and organizational commitment will be achieved properly if the company really understands how to manage existing human resources from the start of job placement and also determines rights and obligations which sometimes often have problems in determining them, this returns to human resource management of transformational leaders who fit the current era. Organizational development will be maximized if it is supported by the presence of qualified human beings (Sudiarta. 2018). Having employees who understand their role for the company and are able to actively contribute to the company who are willing to give all their abilities is the hope for all companies. Human resources in a company are a great asset that belongs to every organization, therefore employees in the company must be managed properly and correctly in order to achieve the expectations of a company but in practice it is not easy to apply this management. Because employees have different thoughts, status and backgrounds, in this case transformational leadership is expected to foster and develop the existing organizational commitment so that it can increase and the value of job satisfaction is formed.

In the world of work that is increasingly developing and dynamic, where tasks are increasingly being carried out in teams, more flexible, of important value, it is necessary to have employees who are able to behave outside of their roles. Some examples include: 
making constructive statements for the work of their work group and the company, helping others in the team, volunteering for extra task activities, avoiding unnecessary conflicts, showing concern, respecting and tolerating work-related burdens and distractions that sometimes occur. This condition makes the company really need employees who are willing to do things that are not their job.

Organizational commitment is an important factor that plays a role in shaping the success of a company. Employee organizational commitment is a form of identification, loyalty and involvement expressed by employees towards the organization. Employees who feel more committed to the organization have reliable habits, plan to stay longer in the organization, and put more effort into working (Lamidi. 2009). Organizational commitment is an attitude that reflects employee loyalty to the company and a continuous process where members of the organization express their concern for the organization on the success and sustainable progress (Nagar. 2012).

Based on previous research, the relationship between transformational leadership, commitment and job satisfaction still occurs in results gaps. Some researchers say that leadership does not always affect the formation of commitment and job satisfaction. We pay great attention to the problem by criticizing that many researchers ignore this type of leadership. therefore we try to understand the characteristics of the leadership adopted in the object of research and we find the dominant transformational type. this is what distinguishes our study with several previous studies. Our objectives are as follows: (a) to find out the influence of Transformational Leadership on employee job satisfaction; (b) to find out the influence of Transformational Leadership on Organizational Commitment; and (c) to find out the influence of Organizational Commitment on employee job satisfaction.

\section{Literature and Hypotheses Development}

The Influence of Transformational Leadership on Employee Job Satisfaction

Transformational leadership that is carried out by a leader or manager in directing and moving his subordinates to achieve the planned goals is important in an organization. This is in accordance with the opinion that the role of leaders in the organization is very central in achieving the goals of the various targets previously set. Leadership has a function of determining direction in achieving goals, representatives and spokespersons for organizations, communicators, mediators and integrators. According to Siagian (2005) leadership behavior has a tendency towards two things, the consideration or relationship with subordinates and the initiation structure or the results achieved. The leadership tendency describes a close relationship with subordinates, for example being friendly, helping and defending the interests of subordinates,

The tendency of a leader to set boundaries between the role of the leader and subordinates in achieving goals, giving instructions for carrying out tasks (when, how and what results will be achieved). Leaders in carrying out leadership tasks can always pay attention to aspirations and can also manage tasks that must be considered properly, will be able to create a feeling of pleasure in employees towards the leader so as to create job satisfaction. 


\section{H1. Transformational Leadership has a positive effect on Employee Job Satisfaction}

The Influence of Transformational Leadership on Organizational Commitment

According to Bass (1990) a leader is said to be transformational if he or she can increase awareness in followers or subordinates about what is right, good and important, helping followers to have needs and even develop them. To be able to generate productivity, transformational leadership has been defined as "4 I's" (Four I's) - idealist influence (individualized influence), leaders set high standards of moral and ethical behavior, and use the ability to mobilize individuals and groups towards the achievement of a common mission, inspirational motivation, the leader acts as a role model for followers, communicates a vision of commitment to organizational goals and directs followers' efforts, intellectual stimulation, transformational leaders create stimuli for followers to think creatively and innovatively by providing question assumptions, redesigning problems that have occurred in the past to be resolved by followers in new ways, and individualized consideration, the leader pays personal attention to subordinates, the leader provides services to subordinates as mentors, examining the needs of subordinates for development and increased success. Transformational leadership style is able to influence the existence of organizational commitment to employees. Where a leader is able to provide motivation and encourage subordinates to carry out their duties responsibly so that the goals of the company can be achieved properly. With organizational commitment, employees will be loyal and willing to give their energy and abilities in helping the development of the company. The relationship between superiors and subordinates must be well-established so as to create a conducive working atmosphere.

\section{H2. Transformational leadership positively and significantly influences organizational commitment.}

The influence of organizational commitment on Employee Job Satisfaction

According to Meyer and Allen (1997) that organizational commitment is a psychological attachment based on three forms (Three-Component Model of Organizational Commitment); affective, normative, and continuance commitment. Broadly speaking, job satisfaction will increase as employee job satisfaction increases, which means that the effect will be positive which will also be proven in this study, because this will be realized when an employee feels high ownership in the organization where the employee works, then this is the case. concerning organizational matters will make the employee feel like the problem is too. Thus the commitment that arises in the organization has a major effect on job satisfaction in the company (Emmanuel and Zubair. 2015). Kaihatu and Wahju (2007) state that organizational commitment consists of three dimensions. First, employees with a strong affective commitment (recognition and attachment to the organization) to work continuously because they want to do it (want to do). Second, employees who have a relationship with the organization that are based on a continuance commitment (realizing the costs associated with leaving the organization) are expected to remain in the organization because they need to do it (need to do). Third, employees with a normative commitment feel that they should stay (ought to) with the organization ". Smith, Organ and Near (1983) in their research reported that broadly defined as a strong belief from employees to accept the goals and values of the 
organization, the desire to advance for the sake of the organization, and have a strong desire to stay in the organization ". The success of the company as a result of job satisfaction which is affected by organizational commitment will ultimately help the company to be better and develop (Adekola. 2012)

\section{H3. Organizational Commitment has a significant positive effect on Employee Job Satisfaction}

\section{Conceptual framework}

The concept of the influence of each research variable based on the description above can be described in the conceptual framework model as follows

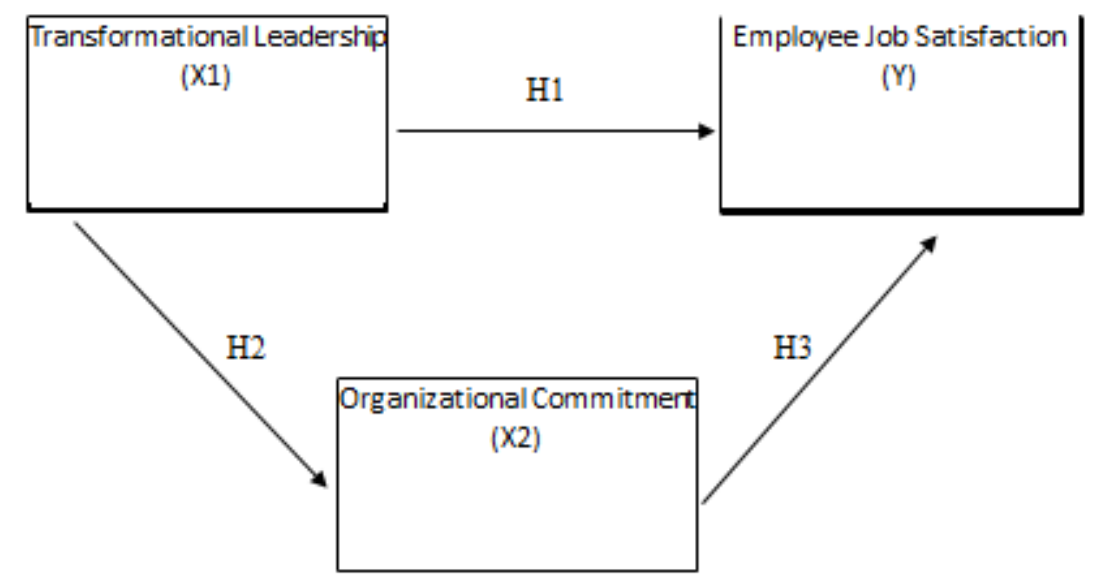

Figure 1. Research Model

\section{Materials and Methods}

\subsection{Participants, Sample and Procedures}

The population in this study were employees of PT Andhika Lines. East Java. Indonesia, amounting to 75 employees. To get qualified respondents, the sampling technique used purposive sampling with the following criteria: working period of more than 5 years and having a good work reputation. Based on these criteria, then 50 employees were obtained. This sample size is still not ideal due to the limitations of our research. However, the sample size is sufficient for Partial Least Square analysis. This is based on the rule of the tumb 10 times, which requires the minimum number of samples to be 10 times the number of lines or a minimum of 30 samples (Hair Jr. et al. 2013).

\subsection{Measures}

The questionnaire had three components based on extensive literature review include job satisfaction, organizational commitment and job satisfaction. We used the previous literature to measure variables such as Bass and Avolio (1990); Mas'ud (2004); Mathis and Jackson (2001). 


\begin{tabular}{|c|c|}
\hline variable & Indicators \\
\hline Job Satisfaction & $\begin{array}{l}\text { 1. The company appreciates my hard work and loyalty in } \\
\text { accordance with what i expect } \\
\text { 2. I think the company is fair to its employees } \\
\text { 3. My coworkers are friendly and can be easy to work with in } \\
\text { work matters } \\
\text { 4. The relationship between employees and leaders is very } \\
\text { good without distinguishing position } \\
\text { 5. I feel the safety and comfort of working in the company } \\
\text { 6. I believe this company will make me smarter and have } \\
\text { integrity in the process } \\
\text { 7. In my opinion, the community in the company environment } \\
\text { gives a positive appreciation of the existence of the company } \\
\text { 8. I feel that the leadership has really thought about the fate of } \\
\text { employees and tried to be optimal in giving appreciation to } \\
\text { employees } \\
\text { 9. Work already feels lighter because harmony is very closely } \\
\text { in the company } \\
\text { 10. Leaders understand the weaknesses and strengths of the } \\
\text { company and wants to think better things for employees }\end{array}$ \\
\hline Organizational Commitment & $\begin{array}{l}\text { 1. I feel happy to be a part of this company } \\
\text { 2. I feel the problems that occur in the company are my } \\
\text { problems too } \\
\text { 3. I am optimistic that the company will get better over time } \\
\text { 4. I feel this company has become like a second home to me } \\
\text { 5. If there is a better choice of work elsewhere } \mathrm{i} \text { will have a } \\
\text { hard time to leave this company } \\
\text { 6. I have a memorable joy and sorrow experience in this } \\
\text { company } \\
\text { 7. If this company were to close } \mathrm{i} \text { would really feel lost, both } \\
\text { losing togetherness with other co-workers or companies that } \\
\text { have been raised together } \\
\text { 8. I consider this company category as an ordinary company } \\
\text { but i have emotional bonds that i didn't get in other } \\
\text { companies where i work before } \\
\text { 9. I sincerely support all activities whether it is my } \\
\text { responsibility or outside of my responsibility aims to the } \\
\text { success of this company } \\
\text { 10. If there are co-workers who discourage my enthusiasm in } \\
\text { this company, i will still be kind and determined to stick } \\
\text { together to pursue achievements in the company }\end{array}$ \\
\hline Transformational Leadership & $\begin{array}{l}\text { 1. Leaders motivate me to work better. } \\
\text { 2. Leaders build my confidence in doing work. } \\
\text { 3. The leader gives me confidence that the company's goals } \\
\text { will be achieved. } \\
\text { 4. The leader sparked my enthusiasm for doing work. } \\
\text { 5. Leaders communicate clearly about work } \\
\text { 6. Leader is my role model (role model) in the company. } \\
\text { 7. Leaders instruct me how to complete a job. } \\
\text { 8. Leaders encourage me to always be innovative in } \\
\text { completing my work. } \\
\text { 9. Leaders solve problems from different perspectives. } \\
\text { 10. My leader treats employees as individuals who each have } \\
\text { different needs, abilities, and aspirations. }\end{array}$ \\
\hline
\end{tabular}




\section{Macrothink}

\subsection{Data Collection}

The data collection method in this study used a questionnaire. The questionnaire was given directly to respondents in all employees and non-employees of PT Andhika Lines. East Java. Indonesia. All items were tested using a five-point Likert scale from 1 (strongly disagree) to 5 (strongly agree).

\subsection{Procedure}

Descriptive statistics are used to describe a situation or problem. In other words, descriptive statistics are statistics that serve to explain a condition or symptom or problem so that it is easy to understand. Drawing conclusions on descriptive statistics is only aimed at existing data sets. Descriptive statistics are an analytical tool to explain, summarize, reduce, simplify, organize and present data in the form of a frequency distribution to find out what the average value of each indicator is and in the form of a percentage, so that it is easy to read, understand and conclude. Adjusting to the objectives and research hypotheses, the use of relevant structural equation techniques (SEM) is carried out. SEM is a statistical modeling technique that is very common and widely used in various sciences. SEM can be seen as a combination of factor analysis (confirmatory factor analysis), and regression or path analysis. Apart from doing the test of it's validity and reliability of the model, SEM analysis also aims to test the suitability of the model in this study. In this study, data analysis used the Partial Least Square (PLS) approach using the Smart PLS software. According to Ghozali Imam, (2006) PLS is an alternative approach that shifts from a covariance-based to variant-based SEM approach. Covariance-based SEM generally tests causality / theory while PLS is more of a predictive model. Since PLS does not assume a certain distribution for parameter estimation, a parametric technique to test the parameter significance is not required Chin, (1998).

\section{Results and Discussion}

Table 1. Respondent Profile

\begin{tabular}{|l|c|c|}
\hline \multicolumn{1}{|c|}{ Information } & Amount & Percentage \\
\hline Age & & \\
-20 Years & $\mathbf{0}$ & 0 \\
21-30 years & $\mathbf{3 4}$ & 68 \\
31 - 40 years & $\mathbf{6}$ & 12 \\
> 40 Years & $\mathbf{1 0}$ & 20 \\
Total & $\mathbf{5 0}$ & $\mathbf{1 0 0}$ \\
\hline Gender & 46 & 92 \\
Male & 4 & $\mathbf{8}$ \\
Women & 50 & $\mathbf{1 0 0}$ \\
Total & & \\
& & \\
Last education & 7 & 14 \\
Junior High & 27 & 54 \\
High school & 7 & 14 \\
3-YEAR DIPLOMA & 9 & 18 \\
BACHELOR DEGREE) & 9 & \\
& & $\mathbf{1 0 0}$ \\
Total & &
\end{tabular}




\section{Macrothink}

International Journal of Human Resource Studies

ISSN 2162-3058

2021, Vol. 11, No. 1

Based on table 1, it appears that the employees in the sample are dominated by productive age. This will be an advantage for the company. Young employees tend to be energetic / have high spirits and are motivated and have many innovations that will benefit the company and greatly help researchers in the research process because at the productive age in this era, they are included in the millennial generation where they are very aware of the needs for development and progress. In the company where they work, this research is actually done to help solve problems in the company and find effective and useful strategies in that era. In the end, because having the same need, productive ages will tend to help this research because surely if it's good for the company it will be good for their organization too. And with the male gender which is the majority compared to women in this service company, it can be used for optimization of technical jobs that can be more helpful in the work mechanism in this type of business that is engaged in ship operation and management, logistics, loading and unloading. ships, custom clearance for export import and heavy equipment rental. As well as education which is in more categories than high school level, companies seem to need to pay attention to training development to acquire special expertise in their fields to get optimal results in business activities within the company.

Table 2. Average Score

\begin{tabular}{|c|c|}
\hline Variable & Average Score \\
\hline $\begin{array}{c}\text { Transformational } \\
\text { leadership }\end{array}$ & 4,294 \\
\hline $\begin{array}{c}\text { Organizational } \\
\text { Commitment }\end{array}$ & 4,278 \\
\hline Job satisfaction & 4,362 \\
\hline
\end{tabular}

Based on the descriptive findings, it appears that the total mean score is in the range above a score of 4 , thus it can be interpreted that the situation of employee job satisfaction, organizational commitment and positive benefits of transformational leadership is very high. This situation is very desired by all organizations where employees really enjoy a transformational leadership style where all obstacles and things that are not desired in the organization can be managed together so that leaders and employees create a harmonious relationship but still uphold mutual respect for one another

\section{Inferential Statistical Analysis}

Testing the Measurement Model (Outer Model)

Below is the output in the form of Outer Loading value from the results of running PLS. 


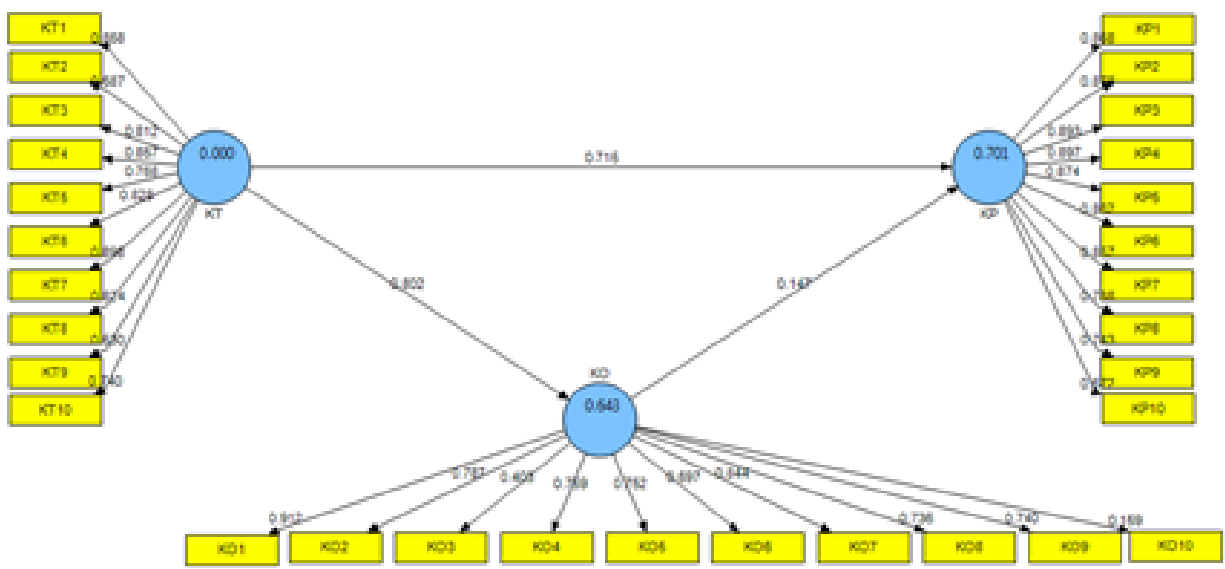

Outer loading on each indicator in the variable Transformational Leadership (KT), Organizational Commitment (KO) and Employee Job Satisfaction (KP) still have a loading value $<0.6$, thus these indicators do not meet the validity requirements and must be removed from the model.

Further testing of the validity is shown in Figure 2 below. Outer loading on each indicator in the Transformational Leadership (KT) variable, Organizational Commitment (KO) and Employee Job Satisfaction (KP) has a loading value of $>0.6$ thus the indicator has met the validity requirements. The construct indicator test can also be seen from the cross loading value which is presented in Table 3 as follows.

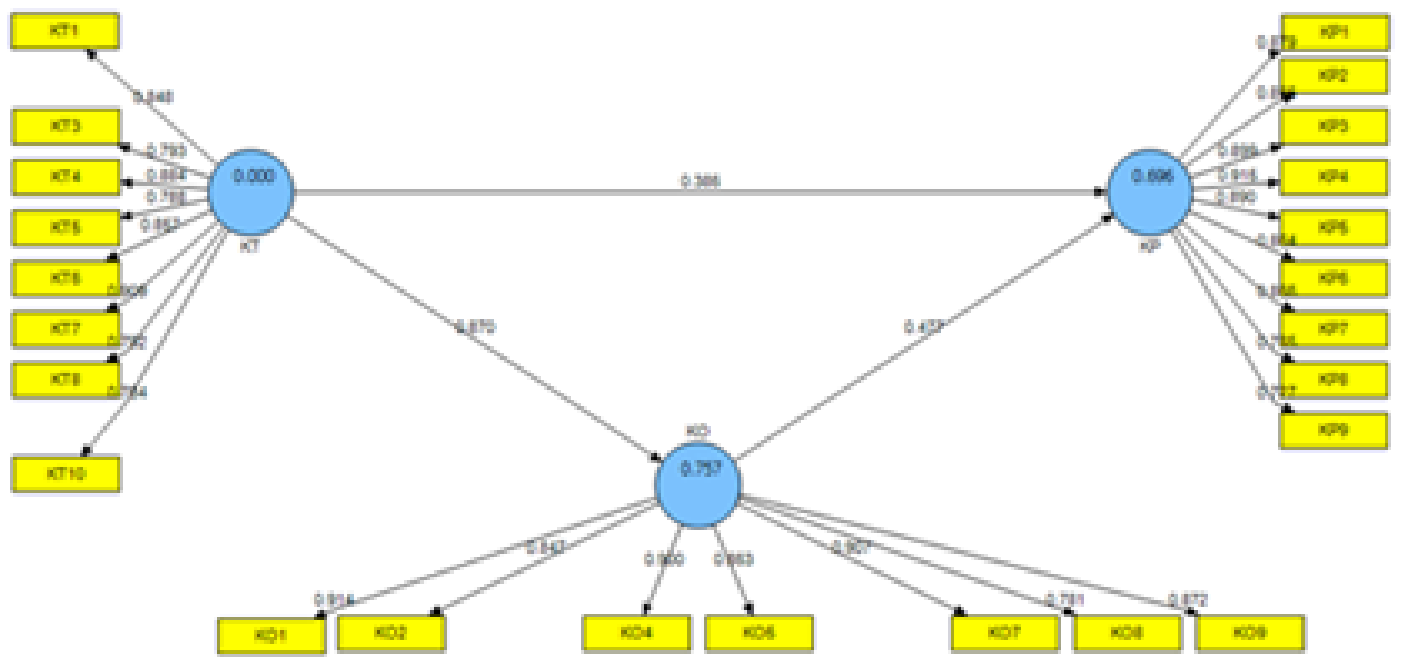

Figure 3. Outer model (final step) 
Table 3. Cross Loading between variables

\begin{tabular}{|c|c|c|c|}
\hline & $\begin{array}{c}\text { Organizational } \\
\text { Commitment (KO) }\end{array}$ & $\begin{array}{c}\text { Employee } \\
\text { Job Satisfaction (KP) }\end{array}$ & $\begin{array}{c}\text { Transformational } \\
\text { Leadership (KT) }\end{array}$ \\
\hline KO1 & 0.913996 & 0.760948 & 0.850446 \\
\hline KO2 & 0.846528 & 0.737244 & 0.770207 \\
\hline KO4 & 0.900180 & 0.699706 & 0.756410 \\
\hline KO5 & 0.863011 & 0.721309 & 0.713958 \\
\hline KO7 & 0.906512 & 0.698279 & 0.709457 \\
\hline KO8 & 0.780743 & 0.597294 & 0.678794 \\
\hline KO9 & 0.871944 & 0.716091 & 0.801169 \\
\hline KP1 & 0.741937 & 0.879046 & 0.726026 \\
\hline KP2 & 0.696879 & 0.885115 & 0.696051 \\
\hline KP3 & 0.723429 & 0.899337 & 0.728399 \\
\hline KP4 & 0.723152 & 0.915359 & 0.678769 \\
\hline KP5 & 0.692206 & 0.890351 & 0.677764 \\
\hline KP6 & 0.709367 & 0.863723 & 0.699649 \\
\hline KP7 & 0.702208 & 0.865842 & 0.693897 \\
\hline KP8 & 0.595222 & 0.785322 & 0.616853 \\
\hline KP9 & 0.674829 & 0.726875 & 0.654171 \\
\hline KT1 & 0.740899 & 0.698112 & 0.847775 \\
\hline KT10 & 0.687728 & 0.606936 & 0.763553 \\
\hline KT3 & 0.674263 & 0.681378 & 0.793380 \\
\hline KT4 & 0.765070 & 0.757435 & 0.884062 \\
\hline KT5 & 0.674822 & 0.651445 & 0.788012 \\
\hline KT6 & 0.754930 & 0.595722 & 0.856543 \\
\hline KT7 & 0.795602 & 0.732997 & 0.909038 \\
\hline KT8 & 0.678594 & 0.573521 & 0.791639 \\
\hline
\end{tabular}

From Table 3, it appears that each indicator has a greater loading value in its construct than in other constructs. Thus convincingly that the indicators have met the validity requirements.

\section{Goodness of fit test}

Table 4. Coefficient of determination

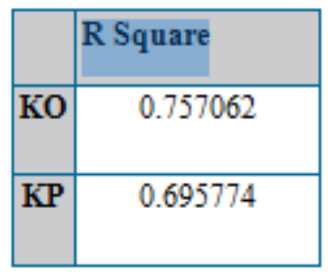

The criteria for the $\mathrm{R}$ square value are classified into three qualities as follows, the $\mathrm{R}$ square 
value of 0.6 is included in the strong, 0.3 moderate and 0.19 weak categories Chin, WW (1998), Table 4 shows that the $\mathrm{R}$ square value on line 1 is equal to 0.757062 (Predictive ability between Transformational Leadership (KT) and Organizational Commitment (KO). Whereas in path 2, it is 0.695774 predictive ability between Transformational Leadership (KT) and Organizational Commitment (KO) on Employee Job Satisfaction (KP). Thus the predictive ability research model is quite good.

Construct Reliability

Construct Reliability (Cronbach alpha measures the reliability of constructs or latent variables) the value must be above 0.70 which is considered reliable. However, for exploratory research, moderate reliability is $0.5-0.6$ which is sufficient to justify Ferdinand's research results. (2006). Table 5 below is a table of the results of Construct reliability.

Table 5. Output Construct Reliability

\begin{tabular}{|c|c|c|c|}
\hline & AVE & Composite Reliability & Cronbachs Alpha \\
\hline KO & 0.756960 & 0.956043 & 0.946046 \\
\hline KP & 0.737371 & 0.961767 & 0.954751 \\
\hline KT & 0.690053 & 0.946664 & 0.935146 \\
\hline
\end{tabular}

From three reliability test parameters (Cronbach alpha, composite and AVE) all have met the minimum standard for AVE> 0.5 while Composite Reliability and Cronbachs Alpha> 0.7. Thus the research instrument convincingly meets the reliability requirements.

Hypothesis testing

As stated in the formulation, research objectives and hypothesis that this thesis tests the extent of Transformational Leadership on Employee Job Satisfaction, either directly or indirectly with Organizational Commitment as an intervening variable.

Table 6. Path Coefficient

\begin{tabular}{|l|l|l|l|l|l|} 
& \multicolumn{1}{|c|}{$\begin{array}{c}\text { Original Sample } \\
(\mathbf{O})\end{array}$} & $\begin{array}{c}\text { Sample Mean } \\
(\mathrm{M})\end{array}$ & $\begin{array}{c}\text { Standard } \\
\text { Deviation } \\
(\text { STDEV) }\end{array}$ & $\begin{array}{c}\text { Standard Error } \\
(\text { STERR) }\end{array}$ & \multicolumn{1}{|c|}{$\begin{array}{c}\text { T Statistics } \\
(\mid \text { O / STERR })\end{array}$} \\
\hline KO $\rightarrow$ KP & 0.476608 & 0.439559 & 0.206258 & 0.206258 & 2.310739 \\
\hline KT $\rightarrow$ KO & 0.870093 & 0.868363 & 0.054181 & 0.054181 & 16.058961 \\
\hline KT $\rightarrow$ KP & 0.385675 & 0.426383 & 0.204409 & 0.204409 & 1.886784 \\
\hline
\end{tabular}

T table $(0.05 ; 47)=2,0128$

Based on table 6 it can be concluded that there is no proven positive and significant influence between Transformational Leadership (KT) on Employee Job Satisfaction (KP) with a path coefficient of 0.385 (1.886<t-table). There is a positive and significant influence between 


\section{Mll Macrothink}

International Journal of Human Resource Studies

ISSN 2162-3058

2021, Vol. 11, No. 1

Transformational Leadership (KT) on Organizational Commitment (KO) with a path coefficient of 0.870 (16.058> t table). There is a positive and significant influence between Organizational Commitment (KO) on Employee Job Satisfaction (KP) with a path coefficient of 0.476 (2.310>t table). Thus Organizational Commitment (KO) is proven to be an absolute intervening variable.

\section{Discussion}

\subsection{Transformational Leadership on Employee Job Satisfaction}

The results of this study indicate the suitability of research conducted by Bushra (2011); Wijayanti (2014) with the finding that transformational leadership has a positive effect on employee job satisfaction, but it is not significant at PT Andhika Lines. East Java researchers see transformational leadership really plays an active role and contributes to increasing job satisfaction, it's just that the results of this influence are still less effective, in the findings of this study, transformational leadership styles will be more effective with organizational commitment as the media that bridges transformational leadership to job satisfaction itself.

\subsection{Transformational Leadership on Organizational Commitment}

The results of research on the effect of transformational leadership on organizational commitment are very significant, this is in line with the findings of Lamidi, (2009); Sari et al (2017) showing that transformational leadership has an effect on organizational commitment, transformational leadership on organizational commitment is needed because when organizational commitment increases, employees can appreciate the company more. where the employee works, and in this case it is closely related to the results of this study where the leader who devotes his attention to the problems faced by his followers and the development needs of each of his followers by providing enthusiasm and encouragement to achieve the company's vision and mission is proven. succeeded in increasing employee organizational commitment, then it can be seen that the results of the influence of transformational leadership on organizational commitment can create big differences and changes within the organization and raising subordinate colleagues to achieve a greater awareness of their role in the organization. In general, organizational commitment arises because employees get comfort and a sense of security in an organization.

\subsection{Organizational Commitment on Employee Job Satisfaction}

The results of this study are in line with the research of Adekola (2012); Akhtar et al (2015); Testa (1999) which shows that organizational commitment plays a major role in influencing employee job satisfaction and even fluctuations in job satisfaction values are highly dependent and adjusting to the value of organizational commitment in each company itself. The results can be seen where organizational commitment which is influenced by transformational leadership has an influence on employee job satisfaction which makes employees have more innovative innovations that have never been done before. This makes transformational leadership that creates ideal and ultimately organizational commitment able to define, communicate and articulate the organizational vision and mission of PT Andhika Lines. East Java. Indonesia. We find that subordinates can accept and acknowledge the 
credibility of leaders in this organization after organizational commitment increases employee job satisfaction. Thus, transformational leaders are charismatic leaders and have a central and strategic role in bringing the organization to its goals.

\section{Conclusions}

Human resources owned by PT Andhika Lines. East Java. Indonesia is an important asset in achieving company goals. Transformational leadership can be a way for companies to optimize these important assets and bring them to the corporate state that every organization desires. that is, as stated by Kala'lembang, (2015) transformational leaders are believed to be able to bring better change, employee management is highly dependent on the leadership qualities of the organization.

The results showed that the transformational leadership style had no significant effect on satisfaction. However, transformational leadership has a positive and very significant effect on organizational commitment. Furthermore, organizational commitment as an intervening variable has a positive and significant effect on job satisfaction.

\section{The Implications of the Study}

PT Andhika Lines. East Java. Indonesia is a large company owned by the Andhika Group. Where the company is not only located in East Java. Indonesia as researched by current researchers. The results of the study indicate the success of a transformational leadership style at PT Andhika Lines, East Java where employee job satisfaction can increase along with increased employee organizational commitment to the company. which means that other branches of PT Andhika Lines throughout Indonesia can study the problems in each of these companies and it is hoped that this research can be used as consideration for company leaders, If the company want to maintain success that has been achieved to maintain the quality of employee organizational commitment and employee job satisfaction, full contribution from all employees is needed to keep developing even better in the current era and in the future which could be more complicated than the current era.

\section{Reference}

Adekola, B. (2012). The Impact of Organizational Commitment on Job Satisfaction: A Study of Employees at Nigerian Universities. International Journal of Human Resource Studies, 2(2), 1-17.

Akhtar, A., Durrani, A. B., \& Hassan, W. U. (2015). The impact of organizational commitment on job satisfaction and job performance: An empirical study from Pakistan. IOSR Journal of Business and Management, 17(6), 75-80.

Aribowo, H., \& Alexander, W. (2018). Strategi Inovasi Dalam Rangka Menjaga Keberlanjutan Bisnis Dalam Menghadapi Era Volatility, Uncertainty, Complexity, Dan Ambiguity (VUCA). Jurnal Ilmu Manajemen dan Akuntansi Terapan (JIMAT), 9(1), 51-58

Bass, B. M., \& Avolio, B. J. (1990). The implicationsof transactional and transformational leadership for individual, team, and organizational development. Research in Organizational 
Change and Development, 4, 231-272

Bushra, F., Ahmad, U., \& Asvir, N. (2011). Effect of Transformational Leadership on Employee's Job Satisfaction and Organizational Commitment in Banking Sector of Lahore (Pakistan). International Journal of Business and Social Science, 2(1), 261-267.

Chin, W. W. (1998). The partial least squares approach for structural equation modeling. In G. A. Marcoulides (Ed.), Methodology for business and management. Modern methods for business research (p. 295-336). Lawrence Erlbaum Associates Publishers.

Emmanuel, A. O., \& Zubair, H. (2015). The Effects of Transformational Leadership On Job Satisfaction : A Study On Four and Five Star Hotels in Kuala Lumpur. International Journal Of Accounting \& Business Management, 3(1), 81-91.

Eliyana, A., \& Syamsul, M. M. (2019). Job Satisfaction and Organizational Commitment Effect In the Transformational Leadership Toward Employee Performance. European Research on Management and Business Economics, 25(3), 144-150.

Ferdinand, A. (2006). Metode Penelitian Manajemen. Pedoman penelitian untu penulisan skripsi, tesis dan disertasi ilmu manajemen. Penerbit BP Universitas Diponegoro. Semarang.

Hair Jr, J. F., Hult, G. T. M., Ringle, C., \& Sarstedt, M. (2016). A primer on partial least squares structural equation modeling (PLS-SEM). Sage publications.

Jyoti, J., \& Sonia, B. (2015). Impact of Transformational Leadership on Job Performance: Mediating Role of Leader-Member Exchange and Relational Identification. Sage Open, 1-13.

Kaihatu, T. S. (2007). Kepemimpinan transformasional dan pengaruhnya terhadap kepuasan atas kualitas kehidupan kerja komitmen organisasi dan perilaku ekstra peran: studi pada guru-guru SMU di Kota Surabaya. Jurnal Manajemen dan Kewirausahaan, 9(1), 49-61.

Kala'lembang, Adriani., Budi Eko Soetjipto., dan Sutrisno. (2015). The Effect of Transformational Leadership and Organizational Culture On Employee's Working Performance Through Organizational Commitment. Ijaber, 13(7), 5305-5322.

Khanzada, B., Naeem, S., \& Butt, H. (2018). Impact of transformational leadership on job satisfaction and patient safety outcomes in health sector of Pakistan. J Health Edu Res Dev, 6(2), 251.

Lamidi, L. (2009). Pengaruh Kepemimpinan Transformasional terhadap Komitmen Organisasional dengan Variabel Moderating Kepuasan Kerja Pegawai Rumah Sakit Swasta di PKU Muhammadiyah Surakarta. Jurnal Ekonomi dan Kewirausahaan, 9(1), 23428.

Li, H., Sajjad, N., Wang, Q., Muhammad Ali, A., Khaqan, Z., \& Amina, S. (2019). Influence of transformational leadership on employees' innovative work behavior in sustainable organizations: Test of mediation and moderation processes. Sustainability, 11(6), 1594.

Mas'Ud, F. (2004). Survai diagnosis organisasional konsep dan aplikasi. Badan Penerbit Universitas Diponegoro.

Mathis, R. L., \& Jackson, J. H. (2001). Managemen Sumber daya Manusia. (Jilid satu). PT Salemba Empat, Jakarta. 


\section{Macrothink}

International Journal of Human Resource Studies ISSN 2162-3058 2021, Vol. 11, No. 1

Meyer J. P., \& Allen, N. J. (1997). Commitment in the workplace : Theory, research, and application. Thousand Oaks, CA: Sage Publication.

Nagar, K. (2012). Organizational Commitment and Job Satisfaction among Teachers during Times of Burnout. The Journal for Decision Markets, 37(2), 43-60.

Prabandari, A., \& Riani, A. L. The Effect of Transformational Leadership and Work Motivation on Organizational Citizenship Behavior: Does Work Engagement Matter?. Sebelas Maret Business Review, 2(2).

Pratama, G. (2016). Effect of Transformational Leadership Towards Employee's Performance Through Satisfaction and Moderated by Culture. Jurnal Ekonomi Universitas Esa Unggul, 7(2), 77826.

Sari, K. A. Y., Supartha, W. G., \& Riana, I. G. (2017). Pengaruh Kepemimpinan Transformasional Terhadap Kepuasan Kerja dan Komitmen Organisasional (Studi di Perusahaan Daerah Pasar Kota Denpasar). E-Jurnal Ekonomi dan Bisnis Universitas Udayana, 6, 1-28.

Sudiarta, P. (2018). THE EFFECT OF TRANSFORMATIONAL LEADERSHIP, WORK ENVIRONMENT AND ORGANIZATION COMMITMENT TOWARD JOB SATISFACTION TO INCREASE EMPLOYEES'PERFORMANCE. Jurnal Ekonomi \& Bisnis JAGADITHA, 5(1), 8-32.

Siagian, S. P. (2002). Kiat meningkatkan produktivitas kerja. Jakarta: Rineka Cipta.

Smith, C. A. O. D. W. N. J. P., Organ, D. W., \& Near, J. P. (1983). Organizational citizenship behavior: Its nature and antecedents. Journal of applied psychology, 68(4), 653.

Testa., M. R. (1999). Satisfaction With Organizational Vision, Job Satisfaction and Service Efforts: an Empirical. Investigation. Leadership \& Organizational Development Journal, 20(3), 154-161.

Wijayanti, T. D. (2014). Transformational Leadership Contributions and Job Satisfaction in The Development of Innovative Behavior of Employees. Journal of Economics, Business, and Accountancy Ventura, 17(2), 229-244.

\section{Copyright Disclaimer}

Copyright for this article is retained by the author(s), with first publication rights granted to the journal.

This is an open-access article distributed under the terms and conditions of the Creative Commons Attribution license (http://creativecommons.org/licenses/by/4.0/). 